\title{
VERB PARTICLES AND OV/VO IN THE HISTORY OF ENGLISH*
}

Marion Elenbaas \& Ans van Kemenade

\begin{abstract}
Verb particles (e.g. up, out, off, down, away) are a well-known and well studied feature of English and of Germanic languages in general. Nevertheless, the functional and categorial status of English verb particles remains debated, and, especially in the diachronic literature on OV/VO word-order change, this question is typically avoided entirely. This lack of precision about the nature of verb particles is surprising, given the central role attributed to verb particles as diagnostic elements for basic word order. We motivate an analysis of English verb particles as (optionally) projecting intransitive prepositions which function as secondary predicates. In relation to the $\mathrm{OV} / \mathrm{VO}$ issue, we claim that, although there is a statistically strong cross-Germanic correlation between the position of verb particles and verb complements, the position of verb particles is not a diagnostic for $\mathrm{OV} / \mathrm{VO}$ order. To support this claim, we will show that there is no one-to-one correspondence a) between Prt-V surface word order and an underlying OV grammar, or b) between V-Prt surface word order and an underlying VO grammar. Moreover, it will be shown that OV order with DPobjects in early Middle English is highly discourse-sensitive, suggesting that OV order with DP-objects is not determined by phrase structure, but by discoursesensitive scrambling from a VO base.
\end{abstract}

\section{The status of verb particles in the history of English}

English particle verbs have received a huge amount of attention in the synchronic literature and many different analyses have been proposed to account for their properties (cf. inter alia Bolinger 1971, Fraser 1976, den Dikken 1995, Svenonius 1996, Haegeman \& Guéron 1999, Gries 2000, Dehé 2002, Neeleman 2002, Farrell 2005). Most analyses, however, fail to account for the full range of facts involved. The analysis we will adopt in this article is the one proposed for English in Elenbaas $(2006,2007)$ and Los et al. (2012). This analysis is able to account for the properties of particle verbs at all stages of English, including the shift from pre-verbal to post-verbal particles in the transition from Old to Middle English. In this section, we will discuss two key ingredients of the analysis: verb particles as intransitive prepositions (section 1.1) and verb particles as

\footnotetext{
*We would like to thank the audience at the Particles Workshop, held at the University of Cambridge, 30-31 October 2008, for helpful comments. We would also like to thank the members of the project 'The diachrony of complex predicates in the West Germanic languages', which was funded by the Netherlands Organisation for Scientific Research (NWO) (project no. 360-70-050). The comments of two anonymous referees have been very helpful. Thanks also to Theresa Biberauer for the insightful discussion of theoretical issues concerning $\mathrm{OV} / \mathrm{VO}$. Of course, all remaining errors are ours.
} 
(optionally) projecting secondary predicates (section 1.2). We will also discuss the prosodic weight of verb particles (section 1.3).

\subsection{Verb particles are intransitive prepositions}

Many English verb particles are homophonous with a preposition (e.g. up, out, off, over). We take this to support an analysis of verb particles as a subcategory of the category Preposition (see also inter alia Emonds 1972, Jackendoff 1973, Huddleston \& Pullum 2002, Svenonius 2002, 2003, 2007, and Aarts 2008). Importantly, however, there is a clear difference in syntactic behaviour between verb particles and other prepositions, (1).

(1) Verb particle

\section{Preposition}

(a) She dug up a secret. (a') He climbed up a ladder.

(b) She dug a secret up. $\left(b^{\prime}\right) *$ He climbed a ladder up.

(c) *She dug up it.

(c') He climbed up it.

(d) She dug it up.

$\left(d^{\prime}\right) *$ He climbed it up.

Whereas verb particles can be preceded or followed by a nominal complement (1a-b), prepositions can only be followed by a nominal complement $\left(1 \mathrm{a}^{\prime}-\mathrm{b}^{\prime}\right)$. Additionally, a pronominal complement cannot follow a verb particle $(1 \mathrm{c}-\mathrm{d})$, but must follow a preposition $\left(1 \mathrm{c}^{\prime}-\mathrm{d}^{\prime}\right)$. Svenonius (2003) argues that the nominal complements combining with prepositions and particles belong to different semantic types: prepositions typically combine with a Figure and a Ground or with a Ground, while verb particles typically combine with a Figure. The terms Figure/Ground are Talmy's (1978, 2000), and can be defined as follows:

The Ground is a reference entity, one that has a stationary setting relative to a reference frame, with respect to which the Figure's path, site, or orientation is characterized.

The Figure is a moving or conceptually movable entity whose path, site or orientation is conceived as a variable, the particular value of which is the relevant issue.

(Talmy 2000:312)

Thus, prepositions relate an entity (the Figure) to a certain location (the Ground), (2a), whereas verb particles denote the end-state or -location of an entity (the Figure), leaving the Ground unexpressed, (2b).

(2) (a) He took the hat [pp off $\frac{\text { his head }}{\text { Figure }}$.

(b) He took $\frac{\text { the hat }}{\text { Figure }}[\mathrm{Prt}$ off]. 


\section{Marion Elenbaas \& Ans van Kemenade}

Verb particles, then, do not constitute a separate category: they are intransitive prepositions. ${ }^{1}$ Apart from intransitive prepositions, certain adjectives (e.g. open, clean) and certain nouns (e.g. home) show particle behaviour in that they allow the well-known word-order alternation, illustrated in (3):

(3) (a) He wiped the table clean. / He wiped clean the table.

(b) She brought the stray cat home. / She brought home the stray cat.

The term 'particle' therefore subsumes elements from various word classes (P, A, N) and should strictly speaking be understood as a distributional term. Here we will continue to use the term 'verb particle', taking intransitivity to be a key shared property of these elements.

\subsection{Verb particles are (optionally) projecting secondary predicates}

A typical characteristic of verb particles, observable throughout the history of English, is that they express a complex event in combination with the verb. We illustrate this with the following examples: ${ }^{2,3}$

(4) (a) Late Old English

Đonne Moyses his handa (O3; cootest, Exod: 17.11.3063)

when Moses his hands

up ahof, ...

up raised

'When Moses raised his hands, ...'

(b) Early Middle English

Ha hackede of his heaued (M1; CMANCRIW, II.220.3190) they cleaved off his head

'They cleaved off his head'

\footnotetext{
${ }^{1}$ As Svenonius (2007:80) puts it: "Particle is [then] not a distinct category, but a kind of $\mathrm{P}$ with a particular c-selectional frame [c-selection holds between a head and a complement; ME-AvK]. A given P may be a particle always (like upstairs) or sometimes (like up) or never (like $a t$ ), depending on its own lexical properties."

${ }^{2}$ All examples are from the following sources (text references can be found on the websites): the York-Toronto-Helsinki Parsed Corpus of Old English Prose (Taylor et al. 2003), the Penn-Helsinki Parsed Corpus of Middle English (Kroch \& Taylor 2000b), the Penn-Helsinki Parsed Corpus of Early Modern English (Kroch et al. 2004). Searches were carried out using CorpusSearch (Randall 2003). The Present-Day English examples were extracted from the British National Corpus Online service http://www.natcorp.ox.ac.uk/, managed by Oxford University Computing Services on behalf of the BNC Consortium. All rights in the texts cited are reserved.

${ }^{3}$ The abbreviations $\mathrm{O} 3, \mathrm{M} 1$, etc. refer to time periods as adopted in the corpora used. The division is as follows: Old English: O1 (-850), O2 (850-950), O3 (950-1050), O4 (10501150); Middle English: M1 (1150-1250), M2 (1250-1350), M3 (1350-1420), M4 (14201500); Early Modern English: E1 (1500-1569), E2 (1570-1639), E3 (1640-1710).
} 
(c) Early Modern English

... and tooke up a brick-bat which lay there by

(E2; ARMIN-E2-P2, 38.267)

'.. and picked up a brickbat that lay near there'

(d) Present-Day English

Recovering slightly from the terror of a moment ago, he wondered whether he dared pick up the skull. (BNC, ACV 815)

In each case, the verb particle denotes the end-state of the action expressed by the verb: in the Old English example (4a), Moses' hands are up as a result of raising them, in (4b), his head is off as a result of the cleaving, in example (4c), the brickbat is up as a result of the picking, and in (4d), the skull is up as a result of the picking. These paraphrases reveal that verb particles predicate over a subject and can thus be said to function as secondary predicates syntactically (given that the verb functions syntactically as the primary predicate). This secondary predicate function of verb particles can be seen most clearly when the verb particle has a literal, directional meaning, as in the examples in (4), but verb particles with a non-literal meaning also function as secondary predicates, (5).

(5) ben schalt pou with suche a then shall you with such a

(M3; CMHORSES, 125.394) pouder help up be wounde. powder heal up the wound

'Then, with such a powder you shall heal up the wound.'

The verb particle $u p$ in this late Middle English example has a non-literal meaning, but still denotes an end-state: it expresses completion of the healing action of the wound. It can therefore be said to function as a secondary predicate, predicating over a subject.

Although all examples discussed so far in this section have a verb particle in a position immediately adjacent to the verb, a distinguishing characteristic of English verb particles is that they can be separated from the verb. This is the case at all stages of the history of English; some examples are given in (6).

(6) (a) Late Old English

pa het he (O3; coaelive, ÆLS [Chrysanthus]: 222.7458)

then ordered he

niman Claudium and lædan to sæ, and wurpan

take Claudius and lead to sea and throw

hine ut mid anum weorcstane.

him out with a hewn stone

'then he ordered Claudius to be taken and led to the sea and thrown in with a hewn stone.' 
(b) Early Middle English \& speowen hit ut per and spit it out there 'and spit it out there'

(c) Early Modern English

And with that worde spekyng as he dyd cast his armys out to make his con $\sim$ tenau $\sim$ ce there fell a podynge out of his sleue which he hymself had stole $\sim$ a lytel before in $y=e=$ same alehous

(E1; MERRYTAL-E1-P2, 121.264)

'And with that word, speaking as he did, threw his arms out to make his countenance, there fell a pudding out of his sleeve which he himself had stolen a while before in the same alehouse'

(d) Present-Day English

Despite this, in most areas we are continuing to hold our rates down.

(BNC, AYP 1517)

Verb particles must have been syntactically independent elements in Old English, given the fact that their position changed from predominantly pre-verbal to predominantly post-verbal in the transition from Old to Middle English. This would be unexpected if the particle formed a lexicalised unit with the verb. As syntactically independent elements, there is clear evidence that Old English particles project a phrase: they can be topicalised, (7a), and they can be modified, (7b). In both cases, they are separated from the verb.

(7) (a) Niðer he ahreas... (O3; cocathom1, ÆCHom I, 11:270.111.2078) down he fell

'He fell down ...'

(b) On ane healfe pæs (O3; coaelive, FLS [Martin]: 315.6159)

on one side of the mynstres wæs an ormæte clif ascoren rihte adune, ... monastery was a huge rock cut right down

'A huge rock was cut right down on one side of the monastery, ...'

Although topicalisation of verb particles has been highly restricted throughout the history of English, examples like (7a) are indicative of syntactic independence, i.e. phrasal status of verb particles. The adverb rihte 'right' in ( $7 \mathrm{~b})$ modifies the particle adune 'down' and as such must be assumed to occupy a position inside the projection of the verb particle.

While examples like those in (7) are also attested in Middle English, topicalised verb particles are few and there is a steady decrease in the number and types of elements that are allowed to intervene between the verb and the verb particle (see Elenbaas 2007; Los et al. 2012). 
(8) (a) ... that downe he felle in a (M4; CMMALORY, 206.3390)

that down he fell in a

sowghe to the grounde.

swoon to the ground

'... that he fell down to the ground in a swoon.'

(b) $\ldots$ and the bookis of the olde (M3; CMPURVEY, I,2.74)

and the books of the old

testament, that ben not anentis Ebreies, and bennot

testament that are not among Hebrews and are not

of the noumbre of holy writ, owen to be cast

of the number of holy scriptures have to be cast

fer awey;

far away

' $\ldots$ and the books of the Old Testament that are not among

Hebrews, and that are not of the number of the Holy

Scriptures, have to be thrown far away;'

From early Middle English onward, the adjacent V-Prt order is very much more frequent than the non-adjacent V...Prt order. Tables 1 and 2 give the figures for the position of verb particles with respect to the verb in the first two periods of Middle English, M1 (1150-1250) and M2 (1250-1350).

Table 1a shows that verb particles occur post-verbally in $99.1 \%$ of all main clauses containing a verb particle and a finite verb in the M1 period (1150-1250). For the M2 period (1250-1350), this percentage is $94.4 \%$. Table $1 \mathrm{~b}$ shows that verb particles occur post-verbally in $73.5 \%$ of all main clauses containing a verb particle and a non-finite verb in M1. For M2, this percentage is $90.9 \%$. Table $2 \mathrm{a}$ shows that verb particles occur post-verbally in $87.5 \%$ of all embedded clauses containing a verb particle and a finite verb in M1. For M2, this percentage is $84.2 \%$. Table $2 \mathrm{~b}$ shows that verb particles occur post-verbally in $87.2 \%$ of all embedded

Table 1a. The position of verb particles with respect to the finite verb in M1 (1150-1250) and M2 (1250-1350) main clauses.

\begin{tabular}{|c|c|c|c|c|c|c|c|c|c|c|c|c|c|}
\hline \multirow[b]{3}{*}{ Main } & \multicolumn{6}{|c|}{ Pre-verbal } & \multicolumn{6}{|c|}{ Post-verbal } & \multirow{3}{*}{$\begin{array}{l}\text { Total } \\
\mathrm{V}_{\mathrm{f}}+\mathrm{prt} \\
\text { main } \\
\mathrm{N}\end{array}$} \\
\hline & \multicolumn{2}{|c|}{ prt- $\mathrm{V}_{\mathrm{f}}$} & \multicolumn{2}{|c|}{$\operatorname{prt} \ldots \mathrm{V}_{\mathrm{f}}$} & \multicolumn{2}{|c|}{$\begin{array}{l}\text { Total } \\
\text { Pre }\end{array}$} & \multicolumn{2}{|c|}{$\mathrm{V}_{\mathrm{f}}-$ prt } & \multicolumn{2}{|c|}{$\mathrm{V}_{\mathrm{f}} \ldots$ prt } & \multicolumn{2}{|c|}{$\begin{array}{l}\text { Total } \\
\text { Post }\end{array}$} & \\
\hline & $\mathrm{N}$ & $\%$ & $\mathrm{~N}$ & $\%$ & $\mathrm{~N}$ & $\%$ & $\mathrm{~N}$ & $\%$ & $\mathrm{~N}$ & $\%$ & $\mathrm{~N}$ & $\%$ & \\
\hline M1 & 0 & 0.0 & 1 & 0.9 & 1 & 0.9 & 68 & 58.6 & 47 & 40.5 & 115 & 99.1 & 116 \\
\hline M2 & 3 & 5.6 & 0 & 0.0 & 3 & 5.6 & 45 & 83.3 & 6 & 11.1 & 51 & 94.4 & 54 \\
\hline
\end{tabular}


146 Marion Elenbaas \& Ans van Kemenade

Table 1b. The position of verb particles with respect to the non-finite verb in M1(1150-1250) and M2 (1250-1350) main clauses.

\begin{tabular}{|c|c|c|c|c|c|c|c|c|c|c|c|c|c|}
\hline \multirow[b]{3}{*}{ Main } & \multicolumn{6}{|c|}{ Pre-verbal } & \multicolumn{6}{|c|}{ Post-verbal } & \multirow{3}{*}{$\begin{array}{l}\text { Total } \\
\mathrm{V}_{\mathrm{nf}}+\text { prt } \\
\text { main } \\
\mathrm{N}\end{array}$} \\
\hline & \multicolumn{2}{|c|}{ prt- $\mathrm{V}_{\mathrm{nf}}$} & \multicolumn{2}{|c|}{$\operatorname{prt} \ldots \mathrm{V}_{\mathrm{nf}}$} & \multicolumn{2}{|c|}{$\begin{array}{l}\text { Total } \\
\text { Pre }\end{array}$} & \multicolumn{2}{|c|}{$\mathrm{V}_{\mathrm{nf}}-\mathrm{prt}$} & \multicolumn{2}{|c|}{$\begin{array}{l}\mathrm{V}_{\mathrm{nf}} \ldots \\
\text { prt }\end{array}$} & \multicolumn{2}{|c|}{$\begin{array}{l}\text { Total } \\
\text { Post }\end{array}$} & \\
\hline & $\mathrm{N}$ & $\%$ & $\mathrm{~N}$ & $\%$ & $\mathrm{~N}$ & $\%$ & $\mathrm{~N}$ & $\%$ & $\mathrm{~N}$ & $\%$ & $\mathrm{~N}$ & $\%$ & \\
\hline M1 & 8 & 23.5 & 1 & 2.9 & 9 & 26.5 & 21 & 61.8 & 4 & 11.8 & 25 & 73.5 & 34 \\
\hline M2 & 2 & 9.1 & 0 & 0.0 & 2 & 9.1 & 19 & 86.4 & 1 & 4.5 & 20 & 90.9 & 22 \\
\hline
\end{tabular}

Table 2a. The position of verb particles with respect to the finite verb in M1 (1150-1250) and M2 (1250-1350) embedded clauses.

\begin{tabular}{|c|c|c|c|c|c|c|c|c|c|c|c|c|c|}
\hline \multirow[b]{3}{*}{ Sub } & \multicolumn{6}{|c|}{ Pre-verbal } & \multicolumn{6}{|c|}{ Post-verbal } & \multirow{3}{*}{$\begin{array}{l}\text { Total } \\
\mathrm{V}_{\mathrm{f}}+\mathrm{prt} \\
\text { sub } \\
\mathrm{N}\end{array}$} \\
\hline & \multicolumn{2}{|c|}{ prt- $V_{f}$} & \multicolumn{2}{|c|}{$\operatorname{prt} \ldots \mathrm{V}_{\mathrm{f}}$} & \multicolumn{2}{|c|}{$\begin{array}{l}\text { Total } \\
\text { Pre }\end{array}$} & \multicolumn{2}{|c|}{$\mathrm{V}_{\mathrm{f}}-\mathrm{prt}$} & \multicolumn{2}{|c|}{$\mathrm{V}_{\mathrm{f}} \ldots \mathrm{prt}$} & \multicolumn{2}{|c|}{$\begin{array}{l}\text { Total } \\
\text { Post }\end{array}$} & \\
\hline & $\mathrm{N}$ & $\%$ & $\mathrm{~N}$ & $\%$ & $\mathrm{~N}$ & $\%$ & $\mathrm{~N}$ & $\%$ & $\mathrm{~N}$ & $\%$ & $\mathrm{~N}$ & $\%$ & \\
\hline M1 & 12 & 12.5 & 0 & 0.0 & 12 & 12.5 & 59 & 61.5 & 25 & 26.0 & 84 & 87.5 & 96 \\
\hline M2 & 2 & 10.5 & 1 & 5.3 & 3 & 15.8 & 13 & 68.4 & 3 & 15.8 & 16 & 84.2 & 19 \\
\hline
\end{tabular}

Table $\mathbf{2 b}$. The position of verb particles with respect to the non-finite verb in M1 (1150-1250) and M2 (1250-1350) embedded clauses.

\begin{tabular}{|c|c|c|c|c|c|c|c|c|c|c|c|c|c|}
\hline \multirow[b]{3}{*}{ Sub } & \multicolumn{6}{|c|}{ Pre-verbal } & \multicolumn{6}{|c|}{ Post-verbal } & \multirow{3}{*}{$\begin{array}{l}\text { Total } \\
\mathrm{V}_{\mathrm{nf}}+\text { prt } \\
\text { sub } \\
\mathrm{N}\end{array}$} \\
\hline & \multicolumn{2}{|c|}{ prt- $\mathrm{V}_{\mathrm{nf}}$} & \multicolumn{2}{|c|}{$\operatorname{prt} \ldots \mathrm{V}_{\mathrm{nf}}$} & \multicolumn{2}{|c|}{$\begin{array}{l}\text { Total } \\
\text { Pre }\end{array}$} & \multicolumn{2}{|c|}{$\mathrm{V}_{\mathrm{nf}}-\mathrm{prt}$} & \multicolumn{2}{|c|}{$\mathrm{V}_{\mathrm{nf}} \ldots \mathrm{prt}$} & \multicolumn{2}{|c|}{$\begin{array}{l}\text { Total } \\
\text { Post }\end{array}$} & \\
\hline & $\mathrm{N}$ & $\%$ & $\mathrm{~N}$ & $\%$ & $\mathrm{~N}$ & $\%$ & $\mathrm{~N}$ & $\%$ & $\mathrm{~N}$ & $\%$ & $\mathrm{~N}$ & $\%$ & \\
\hline M1 & 9 & 11.5 & 1 & 1.3 & 10 & 12.8 & 56 & 71.8 & 12 & 15.4 & 68 & 87.2 & 78 \\
\hline M2 & 1 & 8.3 & 0 & 0.0 & 1 & 8.3 & 10 & 83.3 & 1 & 8.3 & 11 & 91.7 & 12 \\
\hline
\end{tabular}

clauses containing a verb particle and a non-finite verb in M1. For M2, this percentage is $91.7 \%$.

The predominance of post-verbal particles in early Middle English could signal an increase in syntactic unity between the verb and the verb particle. We hypothesize that this formed a trigger for language learners to analyse verb particles as optionally projecting heads: non-projection is the default by economy, projection is triggered by a restricted set of linguistic factors, such as modification (syntactic factor) and information 
structure (discourse factor). In the case of modification, the verb particle is forced to project a phrase, to host the modifier. For Present-Day English, Dehé (2002) has shown that there is a correlation between information structure and choice of word order: when the object conveys new information, it occurs in a focus position, following the particle verb (V-Prt-DP). When the object conveys given information, it occurs in between the verb and the particle (V-DP-Prt), and it is the particle that occurs in the focus position. On the assumption that focus corresponds with syntactic phrasal status (cf. Lambrecht 1994), the verb particle projects a phrase in these cases (see also Elenbaas 2007; Los et al. 2012).

In the course of the Middle English period, the distribution of verb particles becomes more and more restricted, and by the early Modern English period, they predominantly occur immediately adjacent to the verb (V-Prt), (9a), and can be separated from the verb by (pro)nominal objects, (9b), by a negative adverb, (9c), by a restricted set of adverbs modifying the particle, (9d), or, occasionally, by topicalisation (9e).

(9) (a) ... and tooke up a brick-bat which lay there by

(E2; ARMIN-E2-P2, 38.267)

'.. and picked up a brickbat that lay near there'

(b) For his dissimulacion onelye, kepte all that mischyefe vppe.

(E1; MORERIC-E1-P2, 46.77)

'For his dissimulation only, kept all that mischief up.'

(c) ... taking good heede that thou stirrest not vp furious pleasures, (E1; TURNER-E1-P2, F6V.152)

'... taking good heed that you do not stir up furious pleasures, ...'

(d) hee riseth right vppe

(E2; BLUNDEV-E2-P2, 160V_misnumbered_as_157V.368) 'he rises right up'

(e) But downe they burst the windows for ayre,

(E2; ARMIN-E2-P2, 40.300)

'But down they broke the windows for air, ...'

In (9a), both verb and particle precede the nominal object; the postverbal position of the object may well have been influenced by the fact that it is a heavy object (it contains a relative clause). In (9b), the nominal object intervenes between verb and particle, as it might in Present-Day English. Note that the object is quantified and conveys old information, as indicated by the demonstrative determiner that. The position of the nominal object could have been determined by its discourse-old status, given that discourse-old information strongly tends to precede discoursenew information. Example (9c) shows V-to-I movement, separating the verb from the particle (negative adverb not intervenes). In the midsixteenth century, instances of V-to-I movement are still readily found; the loss of V-to-I movement is certainly later than the sixteenth century 
(cf. Warner 1997). Example (9d) displays a Present-Day English pattern, with the adverb right modifying the verb particle. In (9e), the verb particle has been topicalised.

In sum, verb particles are separable from the verb at all stages of the history of English. Nevertheless, the adjacent verb particle order V-Prt has predominated since early Middle English and since that time, the number and type of elements allowed to intervene between verb and particle has become increasingly restricted, mainly as a result of the loss of V-to-I movement. This can be seen most clearly from modification data, which show that verb particles increasingly appear to resist modification, allowing only a small number of modifiers in Present-Day English. ${ }^{4}$ We take this to mean that the syntactic bond between verb and verb particle has become closer (perhaps also related to the everincreasing idiomatic unity between verb and particle as a result of the development of non-literal meanings), triggering language learners to analyse verb particles as optionally projecting heads. ${ }^{5}$ Crucially, verb particles function as secondary predicates throughout the history of English. ${ }^{6}$ There is no one-to-one correlation between secondary predicate status and syntactic projection: verb particles function as secondary predicates, whether they project or not (cf. Neeleman 1994, 2002).

\subsection{The prosodic weight of verb particles}

In some of the diachronic literature on OV/VO-related issues (e.g. Kroch \& Taylor 2000a, Pintzuk 1997, Pintzuk \& Taylor 2006), it is assumed that verb particles, like pronouns and stranded prepositions, are prosodically light elements. This is a crucial claim for analyses which treat verb particles as diagnostic elements for $\mathrm{OV} / \mathrm{VO}$ word order, because, as light elements, particles are thought to favour occurrence in pre-verbal position in Old English. However, it can be shown that verb particles are not prosodically light at any historical stage in English.

\footnotetext{
${ }^{4}$ Typical particle modifiers in Present-Day English are monosyllabic adverbs such as right and straight (see e.g. Fraser 1976:25-27). Bolinger (1971:11-12) mentions that certain (manner) adverbs, such as gradually, are allowed to intervene between the verb and the particle only when the particle occurs in its most literal sense. It should be noted that it is not always clear that the latter type of adverb modifies (just) the particle.

${ }^{5}$ Several previous analyses of particle verbs have implemented this idea in various ways. See e.g. Zeller (2002) on German particle verbs, Neeleman $(1994,2002)$ on Dutch and English particle verbs, and Toivonen $(2002,2003)$ on Swedish particle verbs.

${ }^{6}$ It should be noted that Present-Day English features particle verbs in which the particle no longer clearly acts as a predicate (e.g. cook up 'invent', figure out 'understand'). This appears to be the result of the development of non-literal meanings, fostering the unit-like character of verb and particle. In our analysis, this means that Present-Day English particles predominantly do not project (are heads rather than phrases) and form a syntactic complex head with the verb (see section 2.1). Present-Day English particles, then, appear to have undergone a certain amount of grammaticalisation.
} 
In Old English and Middle English alliterative poetry, verb particles carry primary stress, as in (10) and (11) respectively, where the particle occurs in an alliterating position.

/ Sie sio bær gearo, | (Beowulf, 3105-6) be the byre ready

ædre geæfned, / ponne we ut cymen speedily made when we out come

'Let the byre be made ready, speedily wrought, when we come out'

(b) I Fyrst fordh gewat; / flota waes on (Beowulf, 210-211) time forth fled/ship was on ydhum, / bat under beorge. waves boat beneath cliff

'Time passed on; the ship was on the waves.'

(11) Thanne fette Favel (ca 1370-1385; Piers Plowman, B, II) then fetched $\overline{\text { Flattery }}$

forth floryns ynowe

forth florins enough

'So Flattery produced a great supply of florins'

In the end-rhyme poetry found throughout the Middle English period and later periods of English, verb particles comfortably occur in rhyming position, as in (12).

(12) For whan he spak, he was anon bore doun

for when he spoke, he was at once overcome

with hende Nicholas and Alisoun.

by pleasant Nicholas and Alison

(ca 1387-1400; The Miller's Tale, 3831-3832)

'For when he spoke, his testimony was at once contradicted by pleasant Nicholas and Alison.'

The fact that verb particles are not prosodically light is in line with our claim that they (optionally) project a phrase.

In the next section, we will look more closely at the syntactic distribution of verb particles in Old and Middle English, focusing on the question of what it tells us about underlying $\mathrm{OV} / \mathrm{VO}$ word order.

\section{The position of verb particles and $\mathrm{OV} / \mathrm{VO}$ word order}

In the transition from Old to Middle English, verb particles shifted from pre-verbal position to post-verbal position. The dramatic nature of the shift can be seen from the fact that post-verbal particles are predominant from earliest Middle English, as discussed above in connection with Tables 1 and 2 (see also Hiltunen 1983; Elenbaas 2006, 
2007; Los et al. 2012). This shift in the position of verb particles has often been linked to the loss of OV word order. However, the connection appears to have been less direct than has been suggested, given the high frequency of post-verbal particles at a time when OV word orders had by no means disappeared from the language. Although there is a statistically strong cross-Germanic correlation between the position of particles and verb complements in the present-day languages, we show that there is enough evidence to suggest that the assumption that verb particles are a diagnostic for $\mathrm{OV} / \mathrm{VO}$ order is too strong. To support this claim, we will show that there is no one-to-one correspondence a) between Prt-V surface word order and an underlying OV grammar, or b) between V-Prt surface word order and an underlying $\mathrm{VO}$ grammar.

Let us first sketch the background of the debate. Pintzuk (1997), Kroch \& Taylor (2000a), Pintzuk (2002) analyse Old English word order and the transition from Old English to Middle English in terms of phrase structure competition between base orders at the level of VP (OV/VO) and at the level of IP (I-medial/I-final), yielding the following four logical possibilities:
(a) [IP subject [I, I [ [vp OV]]]
(b) [IP subject [I, I [ [ve VO $]]]$
(c) [IP subject [I, [vp OV] I]]
(d) [IP subject [I, [vp $\mathrm{VO}] \mathrm{I}]]$

We focus here on what they call competition between $\mathrm{OV}$ and VO grammars, i.e. between (13a) and (13b) on the one hand, and (13c) and (13d) on the other hand. We will disregard option (13d), as this is recognized to be non-existent across the Germanic languages, although no broadly accepted account for this is available in the literature. $^{7}$

Pintzuk (1997), Kroch \& Taylor (2000a), Pintzuk (2002) take the diagnostic for $\mathrm{OV}$ and $\mathrm{VO}$ grammars to consist crucially in the position of personal pronoun objects and verb particles with respect to the verb. The rationale behind this is that personal pronouns and particles are light elements, which in Old English tend strongly to appear pre-verbally. If such light elements appear post-verbally, and if this post-verbal position cannot be attributed to movement of the particle (the assumption being that light elements do not move) or to independently motivated grammatical processes such as fronting of the finite verb, we are crucially looking at the product of a VO grammar.

\footnotetext{
${ }^{7}$ The absence of this word order is known as the Final-over-Final Constraint (FOFC), which rules out a head-final phrase dominating a categorially alike head-initial phrase; see Biberauer, Holmberg \& Roberts 2007 and other publications of the Cambridge/Newcastle research project 'Structure and Linearization in Disharmonic Word Orders'; http://research. ncl.ac.uk/linearization/papers.php).
} 
In the previous section, we presented evidence that particles are not prosodically light. Many particles are short, monosyllabic words, but this is not true for all of them (e.g. adun 'down', niðer 'down'); they carry primary stress, function as secondary predicates, they project a phrase and thus behave like phrases in Old English, as shown in section 1.

The analyses in Pintzuk (1997), Kroch \& Taylor (2000a), Pintzuk (2002) represent a strong claim about the correlation between OV word order/pre-verbal particle on the one hand, and VO order/post-verbal particle on the other hand. Kroch \& Taylor (2000a) claim specifically that leftward scrambling of a DP object that is not quantified or negated, is not possible in a VO grammar (see also Haider 2005, 2007). This is based on the observation that the present-day Germanic VO languages effectively do not allow scrambling unless special conditions obtain such as Holmberg's Generalization (first stated in Holmberg 1986). However, Holmberg's generalization is generally considered relevant only for strict VO languages. The claim in the work of Kroch et al. amounts to saying that any OV order with a (non-negated, non-quantified) DP-object is the product of an OV grammar. Likewise, it implies that any VO word order in which the particle is pre-verbal is the product of an OV grammar in which the object is post-posed, where post-posing is favoured primarily by weight (in number of syllables). More recently, Pintzuk \& Taylor (2008) find that post-posing is also favoured for discourse-new DPobjects.

We here pursue an analysis in which Old English word order is derived from a VO base, following Kayne (1994) in general, and Biberauer \& Roberts (2005) in particular, and combine it with the analysis of verbparticle order to be presented in section 2.1, following Elenbaas (2006, 2007) (see also Los et al. 2012). In such an analysis, a rather liberal process of post-posing is dubious on theoretical grounds.

\subsection{An analysis of Old English and Early Middle English word order}

In order to account for the syntactic distribution of verb particles in Old and Middle English (including the shift from pre-verbal to post-verbal in the transition from Old to Middle English), we adopt Biberauer \& Roberts' (2005) (henceforth B\&R) analysis of Old (and Middle) English word order patterns and extend it with our analysis of verb particles (B\&R are not explicit on the status of verb particles). The analysis makes use of the idea that a head can be a Probe and that it can be associated with an EPP feature (see e.g. Chomsky 2000). A Probe is an element with uninterpretable features which searches ('probes') for a Goal, i.e. an element with matching interpretable features. They assume that Old English has two ways of satisfying the Extended Projection Principle (EPP): the EPP feature of $v$ and $\mathrm{T}$ can be checked either by movement of the constituent containing a D feature (i.e. the object and the subject 


\section{Marion Elenbaas \& Ans van Kemenade}

respectively), (14a), or by movement of the maximal projection containing that constituent (i.e. VP and $v \mathrm{P}$ respectively), (14b).

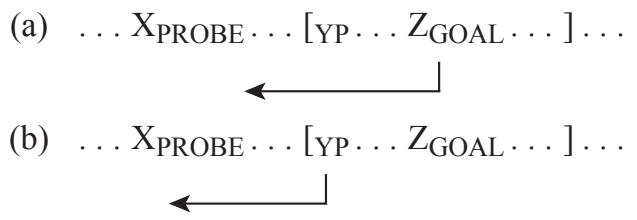

The latter option is called pied-piping, because the constituent containing the EPP feature is moved along in the larger YP containing it. Old English, then, is a spec-pied-piping language (B\&R 2005:9-10).

In section 1.2, we argued that Old English verb particles project a phrase and function as secondary predicates. The basic structure we propose for Old English particle verbs is presented in (15b).

(15) (a) Moyses aðenode his gyrde upp. (O3; cootest, Exod: 9.23.2720) Moses lifted his staff up 'Moses lifted his staff up.'

(b)

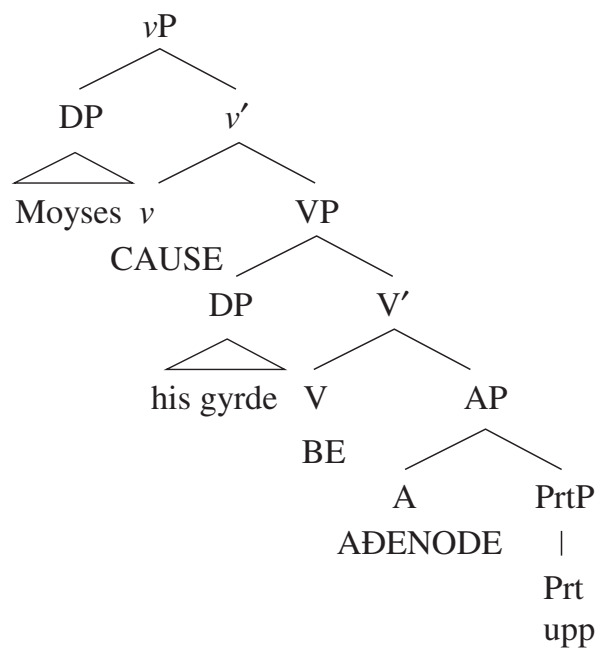

In our discussion of (15b), we assume that it represents the basic structure of a V + object + Prt combination, abstracting away from specific clausal syntax, such as the main clause/embedded clause distinction, the possibility of V-movement and so on. Structure (15b), based on Baker's (2003) lexical decomposition analysis of transitive verbs, presents the lexical decomposition of the particle verb upaðenian 'to lift up', consisting of a BE operator which establishes a semantic relation between the Theme argument (his gyrde 'his staff'), the secondary predicate (the verb particle upp 'up'), and a CAUSE operator which establishes a semantic relation between the Agent 
argument (Moyses 'Moses') and the BE predication. ${ }^{8}$ In (15b), V' represents a complex predicate which predicates over the DP his gyrde in $[$ Spec, VP]. The verb is derived by head movement of the abstract adjectival head $\mathrm{A}$ to $\mathrm{V}$ to $v$. The structure represents the complex event semantics of particle verbs, with the verb particle expressing a result, and also represents the syntactically independent status of Old English verb particles (Old English verb particles project a phrase; see section 1.2) and their secondary predicate status (they predicate over the Theme argument, a Figure). In addition to head movement of the abstract adjectival head, the derivation of the V-DP-Prt pattern illustrated in (15a) involves DP-object movement to (outer) [Spec, $v \mathrm{P}]$ to satisfy $v$ 's EPP feature. ${ }^{9}$

(16) randomly lists the word orders of object, particle and verb that are attested in Old English and Middle English; Tables 3 and 4 give an overview of their distribution. ${ }^{10,11}$

(16) (A) object-particle-verb

(B) particle-verb-object

(C) verb-object-particle

(D) verb-particle-object

(E) object-verb-particle

The percentages in Tables 3 and 4 are the result of dividing $N$ (the number of instances of a particular Prt $+\mathrm{V}+$ object pattern) by the total number of main clauses (Table 3 ) or embedded clauses (Table 4) containing a Prt $+\mathrm{V}+$ object. The label 'DP' includes nominal objects only. Examples in which the pattern is interrupted by a subject, adverb or PP were excluded.

The tables show a dramatic increase in pattern (D), in which the verb particle is immediately post-verbal and followed by a nominal DP object. Pattern $(\mathrm{C})$, in which the verb-particle string is interrupted by a nominal DP object, is less frequent; this order is most frequently attested with pronominal objects, which obligatorily occur between the verb and the particle (cf. Present-Day English). The figures for patterns (B), (C) and

\footnotetext{
${ }^{8}$ See also Jackendoff's (1990) Lexical Conceptual Structure (LCS) and Spencer and Zaretskaya's (1998) Resultative Lexical Conceptual Structure (R-LCS). The latter is applied to particle verbs in van Kemenade and Los (2003).

${ }^{9}$ The adoption of inner/outer [Spec, $\left.v \mathrm{P}\right]$ is in accordance with Biberauer \& Roberts (2005).

${ }^{10}$ Cases in which the particle is followed by a PP, such a (i) are not included here:

(i) ðeah ðu sie up ofer ðine mæð ahæfen (cocura,CP: 65.467.1.3392) though you are up over your condition raised

'although you are raised above your condition'

${ }^{11}$ One logically possible word order, particle-object-verb, is absent from this list, because it is not attested in late Old English and early Middle English, parallel to the order non-finite verb-object-finite verb as in (13d) above, which seems to be systematically absent in the Germanic languages past and present. It has been claimed that this order should be excluded on theoretical grounds, see Biberauer et. al (2007) and references cited there.
} 
154 Marion Elenbaas \& Ans van Kemenade

Table 3. Particle verb + object patterns in late Old English and early Middle English main clauses.

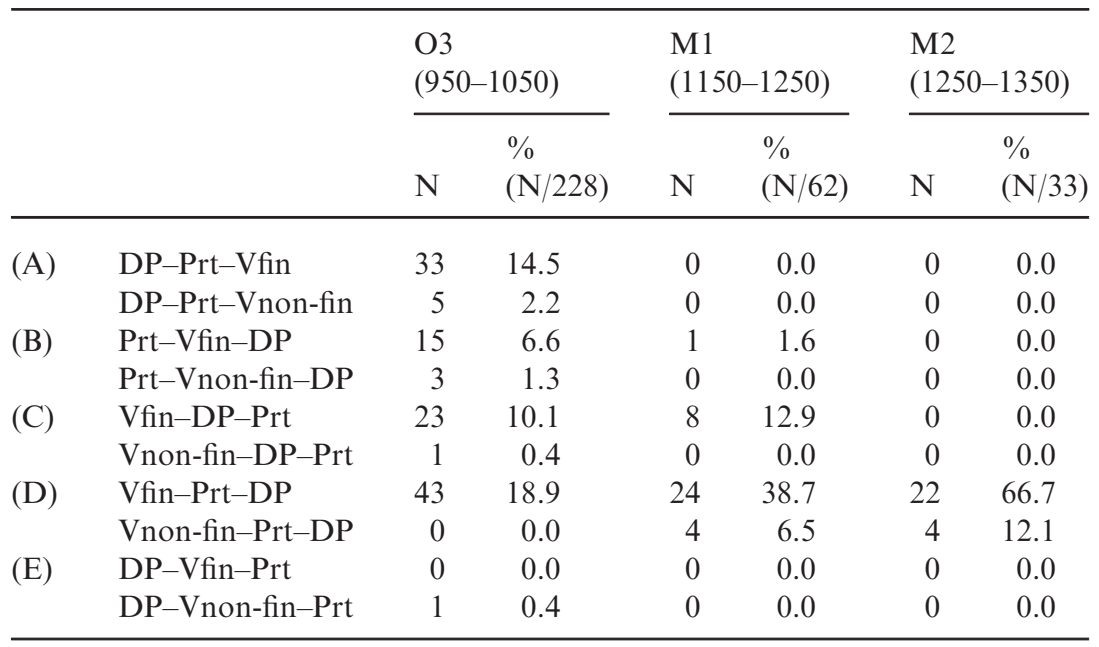

Table 4. Particle verb + object patterns in late Old English and early Middle English embedded clauses.

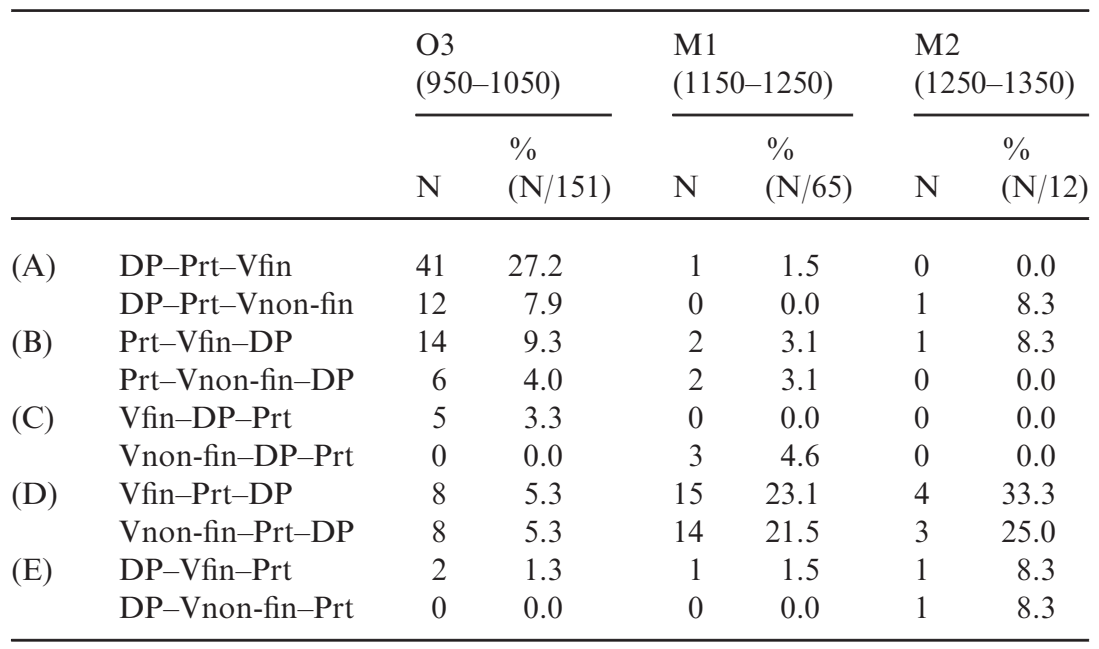

(E) are low in all three periods, but they are attested, and should be accounted for.

For the analysis in Pintzuk (1997), Kroch \& Taylor (2000a), Pintzuk (2002), pattern (B) is problematic in the sense that they are forced to derive pattern (B) with a rather liberal rule of post-posing the object from an OV grammar (since the particle is pre-verbal). Furthermore, pattern (E) cannot be derived in their approach, since the post-verbal particle 
indicates a VO grammar, in which DP-scrambling to the left is disallowed. The various word order patterns and their derivations are now discussed in turn:

Pattern (A) is by far the most frequent one in Old English and is illustrated in (17a). In the analysis of Pintzuk (1997), Kroch \& Taylor (2000a), Pintzuk (2002), this pattern is (unproblematically) analysed as OV and I-final (as in (13c)). Our derivation is given in (17b).

(a) ... pæt he done cwelmbaran hlaf awegbære.

that he the deadly loaf away-carries

(O3; cocathom2, ÆCHom II, 11:96.146.1988)

'... that he carries away the deadly loaf of bread.'

(b) (i) A-to-V-to- $v$ raising:

$\left[{ }_{\mathrm{vP}}[\mathrm{A}+\mathrm{v}+v\right.$ boere $][\mathrm{vP}$ done hlaf $[\mathrm{A}+\mathrm{v} \mathrm{t}][\mathrm{AP}[\mathrm{A} \mathrm{t}]$

[PrtP aweg]]]]

(ii) VP-to-(inner) $[\mathrm{Spec}, v \mathrm{P}]$ movement:

[vP [vP ðone hlaf $[\mathrm{A}+\mathrm{v} \mathrm{t}][\mathrm{AP}[\mathrm{A} \mathrm{t}][\mathrm{PrtP}$ aweg] $]]$

$\left[\mathrm{A}+\mathrm{v}+{ }_{v}\right.$ boere $\left.][\mathrm{vP} \mathrm{t}]\right]$

(iii) merger of the subject in the topmost $[\mathrm{Spec}, v \mathrm{P}]$ :

[vP he [vP ðone hlaf $[\mathrm{A}+\mathrm{v} \mathrm{t}][\mathrm{AP}[\mathrm{A} \mathrm{t}][\mathrm{PrtP}$ aweg]]]

$[\mathrm{A}+\mathrm{v}+v$ bore $][\mathrm{vP} \mathrm{t}]]$

(iv) $v$-to- $\mathrm{T}$ raising:

$\left[\mathrm{TP}[\mathrm{A}+\mathrm{v}+v+\mathrm{T}\right.$ baere $]\left[_{\mathrm{vP}}\right.$ he $\left[\mathrm{vP}\right.$ done hlaf $[\mathrm{A}+\mathrm{v} \mathrm{t}]\left[\mathrm{AP}_{\mathrm{AP}}[\mathrm{A}]\right.$ $[\operatorname{PrtP}$ aweg]]] [v t] [vp t]]]

(v) $v \mathrm{P}$ movement to $[\mathrm{Spec}, \mathrm{TP}]$ :

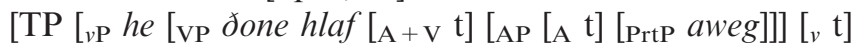
$[\mathrm{vP} \mathrm{t}]][\mathrm{A}+\mathrm{V}+v+\mathrm{T}$ boere $\left.]\left[{ }_{v \mathrm{P}} \mathrm{t}\right]\right]$

In (17), the EPP requirements of $v$ and $\mathrm{T}$ are satisfied by movement of the $\mathrm{VP}$ to $[\mathrm{Spec}, v \mathrm{P}]$ and movement of $\nu \mathrm{P}$ to $[\mathrm{Spec}, \mathrm{TP}]$ respectively.

Another frequent Old English particle verb pattern is Prt-V, in which the verb particle immediately precedes an intransitive verb (no object is present), (18).

(18) $\ldots$ and ic niðer astah.

and I down descended

(O3; cocathom2, ÆCHom II, 12.1:111.43.2403)

'... and I descended.'

The derivation for (18) is the same as that for (17a).

Pattern (B) represents the word order Prt-V-DP, (19). 
156 Marion Elenbaas \& Ans van Kemenade

(19) And ba he utdraf (O3; cowsgosp, Lk [WSCp]: 11.14.4570) and when he out-cast

pa deofolseocnesse ba spræc se dumba,

the demoniacal possession then spoke the dumb

'And when he had cast out the devil, the dumb man spoke'

In the analysis of Pintzuk (1997), Kroch \& Taylor (2000a), Pintzuk (2002), this pattern represents an OV grammar, since the particle is preverbal. They regard pre-verbal light elements, in their view particles and personal pronouns, as a diagnostic for an underlying OV grammar. The position of the object would then be derived by post-posing from an OV structure. In their analysis, post-posing of the object is allowed when the object is heavy, or, according to Pintzuk \& Taylor (2008), discourse new. The following further examples show that this is problematic:

(20) (a) ... and het up ateon ardlice Danihel, and pa in and ordered out pull quickly Daniel, and then in awurpan be hine wregdon ær.

throw who him accused before

(O3; coaelhom, ÆHom 22:333.3473)

'and ordered to pull out Daniel quickly, and to throw in those who had accused him before.'

(b) Đa wæs se hælend utadrifende sume deofolseocnysse, then was the Lord out-driving a devil-sickness

(O3; cowsgosp, Lk [WSCp]: 11.14.4568)

'Then the Lord was driving out a demoniacal possession'

(c) oððе wilt ðu, la, ut apytan ure eagan?

or want you lo out put our eyes

(O3; cootest, Num: 16.14.4218)

'Or do you, lo, want to put out our eyes?'

(d) pa ongan he ford sendan pyllice stemne mid hluddre then began he forth send such a voice with loud clypunga wepende clamour weeping

(O4; comary, LS 23 [MaryofEgypt]: 189.123)

'then he began to send forth such a voice, weeping with loud clamour'

Among the examples in (20), we can say that in at least the examples (20a and c), there is no clear trigger for post-posing in weight or information status: in (20a), Danihel is discourse-old and similarly, in 
(20c) ure eagan is contextually given (since it represents direct speech). ${ }^{12}$ This provides counterevidence to the claims made by Pintzuk (1997), Kroch \& Taylor (2000a), Pintzuk (2002) in the terms of their own analysis.

In our analysis, the derivation for pattern (B) involves remnant VP movement to the (inner) specifier of $v \mathrm{P}$; the object is stranded in its base position (cf. B\&R). Pattern (C) has the word order V-DP-Prt and is exemplified in (21). In our analysis, this pattern is derived as in (15b):
(a) $\ldots$ and man ne mihte swa deah macian $h i$
and one not could so however make them healfe up
half up
(O3; ÆLS(Swithun) 431)
'.. and even in this way not half of them could be put up'
(b) pa wolde seo Sexburh æfter syxtyne gearum then wanted Sexburh after sixteen years do
don hire swustor ban of ðære byrgene up of-her sister bones from the burial-place up
(O3; ÆLS(Æthelthryth) 73)

'After sixteen years Sexburh desired to take up her sister's bones from their burial place'

(c) Gyf hit ponne mædencild wære pone sceolde heo if it then maiden child were then should she hi forhæbban fram ingange godes huses hundeahtatig herself abstain from entry God's house eighty daga eac fram hire gebeddan \& xfter pam fyrste days after her (child) bed and after that period gan mid lace to Godes huse \& beran pat cild go with gift to God's house and bring the child ford mid pære lace:

forth with the gift ... (O3; ÆCHom I, 9:249.8.1571) 'if it should be a girl, then should she refrain from going to church for eighty days after the birth, and after that period of time go to church with a gift, and bring the child forth with the gift'

Observe that Pintzuk (1997), Kroch \& Taylor (2000), Pintzuk (2002) would assume that this is a VO order, since the particle is post-verbal, but their analysis has little to say about the relative order of object and particle.

\footnotetext{
${ }^{12}$ An anonymous reviewer suggests that Danihel could have contrastive focus. If this is the case, Danihel may have been postposed because of information status reasons (cf. Pintzuk \& Taylor 2008). However, the context reveals that Danihel is not contrastive and receives no prominent stress, ruling out a postposing analysis.
} 
Pattern (D) has the word order V-Prt-DP as in (22), which became predominant after the Old English period.

(22) Se hælend ahof upp his eagan

the saviour lifted up his eyes

(O3; cowsgosp, Jn [WSCp]: 11.41.6747)

'The Saviour lifted up his eyes'

In the analysis of Pintzuk (1997), Kroch \& Taylor (2000a), Pintzuk (2002), this represents the structure (13c), with an I-medial IP and a headinitial VP. In our analysis, we interpret this Old English pattern to represent the first cases in which the verb and the particle form a (syntactic) unit: the particle fails to project and merges with the abstract adjective to form a complex syntactic head, (23). ${ }^{13}$

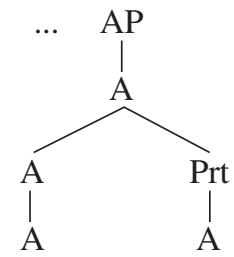

On B\&R's assumption that $v$ has an optional EPP-feature, we assume that it is lacking in this case, which explains the absence of remnant-VP or DP-object movement. We assume that the finite verb has not been moved to $\mathrm{T}$.

Pattern (E) has the word order DP-V-Prt, and is exemplified in (24).

(a) Gif ponne for folces synnum gesceote, swa hit oft
if then for people's sins happen as it often
gescyt pæt unwæstmbernys on eard becymð, pæt
happens that barrenness on earth befalls so that
ma ne mæge pat drincgemett bringan forð, ne
more not may the measure of drink bring forth not
on wine, ne on beore, ne on mede, ne on ealoð,...
in wine nor in beer nor in mead nor in ale
(O4; cochdrul, ChrodR 1:6.28.167)

'If it happens, as it often does on account of people's sins, that barrenness befalls the earth, so that it can no longer provide the measure of drink, in wine, beer, mead or ale,...'

\footnotetext{
${ }^{13}$ Note that the structure in (23) does not violate the Right-hand Head Rule (RHR; Williams 1981), because the complex head is syntactic rather than morphological in nature, which means that it is not subject to morphological conditions such as the RHR.
} 
(b) ... \& ponne he his agene sceap laet ut he and when he his own sheep leads out he gæð beforan him

goes before them (O3; cowsgosp, Jn [WSCp]: 10.4.6600) '.. and when he leads out his own sheep, he goes before them'

In the analysis of Pintzuk (1997), Kroch \& Taylor (2000a), Pintzuk (2002), this pattern is not derivable: the particle is post-verbal, which in their analysis indicates a VO grammar. Since object scrambling is not compatible with a $\mathrm{VO}$ grammar, their analysis predicts that this pattern is not attested. In our analysis, the pattern in (24a) is derived by DP-object movement to the (inner) [Spec, $v \mathrm{P}]$, stranding the particle in the VP. In the analysis of B\&R, the fact that in (24b) the DP object precedes the finite verb (in $T$ ), requires an additional movement of the DP object. We assume that the finite verb is not necessarily moved to $\mathrm{T}$.

After the transition to Middle English, V-Prt predominates and the Old English pre-verbal particle patterns have become a minority (see Tables 1 and 2 above). We present an early Middle English example in (25a) (=4b), along with its derivation in (25b).

(25) (a) Ha hackede of his heaued (M1; CMANCRIW, II.220.3190) he cut off his head

'He cut off his head'

(b) (i) A-to-V-to- $v$ raising:

$\left[{ }_{\mathrm{P}}\left[\mathrm{A}+\mathrm{v}+{ }_{v}\right.\right.$ hackede of $[\mathrm{vP}$ his heaued $\left.[\mathrm{A}+\mathrm{v} \mathrm{t}][\mathrm{A} \mathrm{t}]]\right]$

(ii) DP-object movement to (inner) [Spec, $v \mathrm{P}]$ :

$\left[{ }_{v \mathrm{P}}\right.$ his heaued $\left[\mathrm{A}+\mathrm{V}+v\right.$ hackede of $\left.\left[\mathrm{vP}_{\mathrm{DPP}}[\mathrm{A}+\mathrm{v} \mathrm{t}][\mathrm{A} \mathrm{t}]\right]\right]$

(iii) merger of the subject in the topmost [Spec, $v \mathrm{P}]$ :

[vP Ha his heaued $\left[\mathrm{A}+\mathrm{v}+v\right.$ hackede of $\left[\mathrm{vP} \mathrm{t}_{\mathrm{DP}}[\mathrm{A}+\mathrm{v} \mathrm{t}][\mathrm{A} t]\right]$

(iv) $v$-to-T raising:

[TP $\left[\mathrm{A}+\mathrm{V}+{ }_{v}+\mathrm{T}\right.$ hackede of] ${ }_{v \mathrm{P}}$ Ha his heaued $\left[{ }_{v} \mathrm{t}\right]$

$\left.\left.\left[\mathrm{vP}_{\mathrm{DP}}[\mathrm{A}+\mathrm{v} \mathrm{t}][\mathrm{A} \mathrm{t}]\right]\right]\right]$

(v) DP-subject movement to [Spec,TP]:

[TP $H a\left[\mathrm{~A}+\mathrm{v}+v+\mathrm{T}\right.$ hackede of] ${ }_{v \mathrm{P}} \mathrm{t}_{\mathrm{DP}}$ his heaued $\left[{ }_{v} \mathrm{t}\right]$

$\left.\left.\left[\mathrm{vP} \mathrm{t}_{\mathrm{DP}}[\mathrm{A}+\mathrm{v} \mathrm{t}][\mathrm{A} t]\right]\right]\right]$

In the derivation in (25b), the particle does not project a phrase and merges with the (lexically decomposed) verb to form a complex syntactic head. This complex syntactic head undergoes head movement to $v$ (and $\mathrm{T}$ ) via $\mathrm{V}$. The EPP feature of $v$ is satisfied by movement of the DP-object, 
one of the options in B\&R's analysis. ${ }^{14}$ The EPP feature of T is satisfied by movement of the DP-subject, which was one of the available options, the other being $v \mathrm{P}$ pied-piping, which continued to exist until the end of the Middle English period (B\&R 2005:25). ${ }^{15}$

The above discussion of the Old English patterns shows that the approach of Pintzuk (1997), Kroch \& Taylor (2000a), Pintzuk (2002) is overly rigid in its assumption of a strict OV grammar on the one hand, in which the particle is pre-verbal and in which the object can be liberally moved rightward to post-verbal position, and a strict VO grammar on the other hand, in which the particle is post-verbal and object scrambling to the left is disallowed. At low frequencies, the patterns disallowed in this approach are attested. In our analysis, which in its derivation of Old English word orders follows B\&R and in which the verb particle acts as a secondary predicate and projects a phrase (except in pattern (D), verbparticle-object, in which the particle is non-projecting), all the patterns can be derived straightforwardly.

The situation for Middle English is very similar. The balance of word orders has definitely shifted toward VO in early Middle English, but on the diagnostics of Pintzuk (1997), Kroch \& Taylor (2000a), Pintzuk (2002), in which V-Prt order is a diagnostic for a VO grammar, object DPs may scramble leftward in such a grammar, (26).

$$
\begin{aligned}
& \text { (a) ... \& efsones he let him ut purhe wærse red, } \\
& \text { and afterwards he let him out on worse advice } \\
& \text { to dat forewarde dat he suor on halidom \& } \\
& \text { to the condition that he swore on Holy relics } \\
& \text { gysles fand pat he alle his castles sculde } \\
& \text { and hostages gave that he all his castles } \\
& \text { iiuen up. }
\end{aligned}
$$

should give up

(M1; CMPETERB, 58.571)

' $\ldots$ and soon after, on worse advice, let him out, on condition that he gave hostages and swore on holy relics to yield up all his castles.'

${ }^{14}$ The VP pied-piping option was reanalysed as DP-object movement in early Middle English (B\&R 2005:21). They propose that VP pied piping was reanalysed as object DP movement (stranding the VP) in early Middle English in cases where the VP only contains an object DP, (i) (B\&R 2005:21).

(i) $\left[{ }_{v \mathrm{P}}\left[\mathrm{vP}_{\mathrm{P}} \mathrm{t}_{\mathrm{V}} \mathrm{O}\right] \mathrm{V}+v \mathrm{t}_{\mathrm{VP}}\right]>\left[{ }_{v \mathrm{P}} \mathrm{O} \mathrm{V}+v\left[{ }_{\mathrm{vP}} \mathrm{t}_{\mathrm{V}} \mathrm{t}_{\mathrm{O}}\right]\right]$

$\mathrm{B} \& \mathrm{R}$ suggest that "the reanalysis was caused by a decrease in unambiguous evidence for pied piping" (B\&R 2005: 21). Language learners chose the structurally simpler option of DP movement, ultimately leading to the loss of the pied piping option for checking $v$ 's EPP feature.

15 The (infrequent) Middle English pre-verbal particle patterns are derived as in Old English, via VP pied-piping and $v \mathrm{P}$ pied-piping. 
(b) ... pt swich fulðe spit ut (M1; CMANCRIW, II.66.707) who such filth spits out

in ani ancre earen. me schulde dutten his muð.

in any anchoress's ears one should shut his mouth

Naut mid scharpe sneates ach mid harde fustes.

not with sharp rebukes but with hard fists

'... who spits out such filth in any anchoress's ears, one should shut his mouth. Not with sharp rebukes, but with strong fists.'

Likewise, pre-verbal particles co-occur with a post-verbal DP-object, (27).

(27) ... pat hie mihte nexxin and mealten and ut-sanden that they might soften and melt and out-send

sume tear.

some tears

(M1; CMVICES1, 145.1815)

'... that they might soften and melt and send out some tears.'

We conclude that scrambling is possible from a VO base. We further conclude that all Old and Middle English word orders can be accounted for in an analysis with a VO base; the relative orders of verbs and particles can be derived by principled cases of leftward movement that are independently attested in Old and Middle English and in the Germanic languages more generally.

\section{Discourse-sensitive scrambling in Middle English}

We now discuss a more general argument concerning the OV/VO alternation in early Middle English, which further shows that OV orders can be derived from a VO-base, contra Kroch \& Taylor (2000a). In early Middle English, a good deal of $\mathrm{OV} / \mathrm{VO}$ variation is still attested, as discussed in Fischer et al. (2000), Kroch \& Taylor (2000a), Pintzuk \& Taylor (2006). This is true in particular for pronominal objects, and for quantified and negated objects. So far, DP objects have received comparatively little attention. We will now show that their distribution may contribute significantly to our insight in this period of ongoing loss of OV word order. More particularly, we will show that the distribution of DP objects in early Middle English fully supports the idea that OV orders may be derived by discourse-sensitive scrambling from a VO-base (cf. Foster \& van der Wurff 1997). In the syntactic analysis presented in the previous section, this can be accounted for by movement of the object DP to an inner specifier of $v$, as in Old English patterns such as $(24 a-b)$.

The basic observation here is that, while indefinite DP-objects always occur in VO order, definite DP objects may either occur pre-verbally or post-verbally. In pre-verbal position, they strongly tend towards a 
reading in which they have specific reference to an antecedent in the discourse. Such discourse-sensitivity has been well-established for scrambling in Present-Day Dutch (see e.g. de Hoop 2003; Neeleman \& van de Koot 2008). The early Middle English facts show that pre-verbal position for DP-objects correlates substantially with definiteness and discourse referentiality, supporting the idea that scrambling is discoursedriven and that it is not restricted to basic $\mathrm{VO}$ order, as is often claimed in the literature on the present-day Germanic languages (e.g. Haider 2005).

Let us first present some basic facts concerning OV word order in early Middle English. From the PPCME2 corpus (Kroch \& Taylor 2000b), we gathered all the definite and indefinite objects in the earliest period of Middle English, M1 (1150-1250). The distribution of OV/VO word orders in early Middle English embedded clauses is given in Table 5.

Table 5 shows a sharp contrast between definite and indefinite objects: indefinite objects are always post-verbal, whereas definite objects show a substantial incidence of OV word order. A more detailed look at the data shows a further effect: OV word orders with a definite DP object most typically feature a strong demonstrative pronoun (this, that, these, those as in (28b and 28d)), although relic weak demonstrative pronouns and the new definite determiner the is found here as well (Table 6). ${ }^{16}$

Invariably, pre-verbal definite object DPs refer to a referent that is presupposed in the sense that it is discourse-given. The examples in (28) illustrate this:

(28) (a) All swa he hafð ineðered niðer into helle grunde alle just as he has cast down into hell's ground all ðe modi ðe hier on liue ðe dieule folßeden, alswa the proud who here in life the devil followed so he haueð ihei3ed alle ðo ðе Cristes eadmodnesse he has raised all those who Christ's meekness habbeð 3eluued and ihelden, into heuene riches have loved and kept into heaven's kingdom's merhðe. joy

(M1; CMVICES1,57.4) 'Just as he has cast down into the ground of hell all the proud who in this life followed the devil, so he has raised all those who have loved Christ's meekness and kept it, into the joy of the kingdom of heaven.'

\footnotetext{
${ }^{16}$ By 'relic weak demonstrative pronoun', we understand the relic uses of the Old English demonstratives of the se paradigm, which in Old English was employed to mark definiteness as well. According to van Kemenade (2009), this paradigm in Old English plays a crucial role in the discourse referential marking of definite DPs.
} 
(b) Ne mai no man ðese eadi hope habben, bute he hit not-may no man this blessed hope have, unless he it wel ilieue and soðliche luuie.

well believe and truly love (M1; CMVICES1, 31.351)

'Nobody may have this blessed hope, unless he well believe it and love it truly.'

(c) ... for nan attri ping nemei pe 3imstan

for no poisonous thing not-can the gemstone nach3in. approach

(M1; CMANCRIW II.108.f55v: 15) '... for no poisonous thing can approach the gemstone.'

(d) Meschal leoue sustren peose storien tellen eft ou. one shall dear sisters these stories tell afterwards you

(M1; CMANCRIW,II.122.f64v: 22)

'One shall tell you these stories afterwards, dear sisters.'

It is interesting to note that the object DPs in bold in (28) are not only definite, but they also have a specific reading in that they refer back specifically to a presupposed referent. In context, ðe dieule in (28a)

Table 5. The distribution of definite and indefinite DP objects in the M1 period.

\begin{tabular}{|c|c|c|c|c|}
\hline \multirow{2}{*}{$\begin{array}{l}\text { Embedded clauses } \\
\text { in M1 (1150-1250) }\end{array}$} & \multicolumn{2}{|c|}{ Definite DP objects } & \multicolumn{2}{|c|}{ Indefinite DP objects } \\
\hline & $\mathrm{OV}$ & VO & $\mathrm{OV}$ & VO \\
\hline DPObject - Vfin & $143(21.5 \%)$ & 523 & $0(0 \%)$ & 644 \\
\hline DPObject - Vnon-fin & $47(44.8 \%)$ & 58 & $0(0 \%)$ & 159 \\
\hline Total & 190 & 581 & 0 & 803 \\
\hline
\end{tabular}

Table 6. Types of definiteness markers of preverbal DP objects in the M1 period.

\begin{tabular}{lllll}
\hline $\begin{array}{l}\text { Embedded clauses } \\
\text { with definite object } \\
\text { in M1 (1150-1250) }\end{array}$ & Obj-Vf & Vf-Obj & Vf-Obj-Vn & Vf-Vn-Obj \\
\hline $\begin{array}{l}\text { Strong demonstrative } \\
\text { pronoun }\end{array}$ & $83(58.0 \%)$ & $125(24.0 \%)$ & $24(51.1 \%)$ & $21(36.2 \%)$ \\
$\begin{array}{l}\text { Relic weak demonstrative } \\
\text { pronoun }\end{array}$ & $35(24.4 \%)$ & $187(36.0 \%)$ & $8(17.0 \%)$ & $17(29.3 \%)$ \\
$\begin{array}{l}\text { pe } \\
\text { Total }\end{array}$ & $14(27.6 \%)$ & $208(42.0 \%)$ & $15(31.9 \%)$ & $20(34.5 \%)$ \\
\hline & 143 & 520 & 47 & 58 \\
\hline
\end{tabular}


refers back to dieule two lines up; in (28b), Jese eadi hope refers back to Ja eadi hope in the previous line in the text; in (28c), pe 3imstan refers back to 3imstan two lines up; in (28d), peose storien refers back to the biblical stories that are the topic of the paragraph in which this sentence occurs. Hence, OV order is restricted to definite DPs with a specific reading. A similarly motivated analysis is given in van Kemenade \& Los (2006) and van Kemenade \& Milicev (2011) for subject scrambling in Old English.

It would be very hard to envisage an analysis of these facts on the basis of an OV grammar in which indefinite objects are always post-posed and definite objects optionally so. Furthermore, it would be impossible to account for these facts on the basis of a VO grammar in which leftward scrambling of DP-objects is disallowed. In our view, these facts provide cogent evidence for leftward scrambling of a DP-object from a VO-base, and can be naturally accounted for in the analysis presented here. More generally, they provide evidence that word order in the older stages of English cannot straightforwardly be accounted for as competition between a grammar in which word order is derived from a strict $\mathrm{OV}$ phrase structure or a strict VO phrase structure.

\section{Conclusions}

Summing up, we have motivated an analysis of Old and Middle English word order featuring particle verbs, following up the analysis of Biberauer \& Roberts (2005) in which word order is derived from a VO-base, and combining it with a secondary predicate analysis of verb particles, following Elenbaas (2006, 2007) and Los et al. (2012).

Verb particles are intransitive prepositions which, in combination with an object, behave as secondary predicates in Old English. They have the clause-final focus characteristic of predicates in the West Germanic languages, as reflected in the fact that they carry primary stress. In Old English, verb particles predominantly project a phrase.

In the further history of English, verb particles continue to be secondary predicates, although they undergo semantic bleaching and their positioning with respect to the verb becomes more circumscribed. Verb particles less and less frequently project a phrase.

The position of verb particles is not a typological diagnostic for $\mathrm{OV} /$ VO status. At admittedly low frequencies, OV may combine with a postverbal particle and vice versa. OV word order with DP-objects in Middle English is amenable to an analysis in terms of discourse-sensitive scrambling from a VO base. 


\section{References}

Aarts, B. 2008. English Syntax and Argumentation. Basingstoke and New York: Palgrave MacMillan.

Baker, M. 2003. Lexical Categories: Verbs, Nouns and Adjectives. Cambridge: Cambridge University Press.

Biberauer, T., Holmberg, A. \& Roberts, I. 2007. Disharmonic word-order systems and the Final-over-Final-Constraint (FOFC). Proceedings of the Incontro di Grammatica Generativa XXXIII, ed. A. Bisetto \& F. Barbieri, 86105. Bologna: Il Mulino. [http://amsacta.unibo.it/2397/1/PROCEEDINGS_ IGG33.pdf; last accessed 27 August 2012]

Biberauer, T. \& Roberts, I. 2005. Changing EPP parameters in the history of English: accounting for variation and change. English Language and Linguistics 9(1):5-46.

Bolinger, D. 1971. The phrasal verb in English. Cambridge, MA: Harvard University Press.

Chomsky, N. 2000. Minimalist inquiries: the framework. Step by step, eds. R. Martin, D. Michaels \& J. Uriagereka, 89-156. Cambridge, MA: MIT Press.

Dehé, N. 2002. Particle Verbs in English: Syntax, information structure and intonation. Amsterdam: John Benjamins.

Diknen, M. Den. 1995. Particles: On the Syntax of Verb-Particle, Triadic, and Causative Constructions. Oxford: Oxford University Press.

ElenbaAs, M. 2006. The structural development of the verb-particle combination in the history of English. York Papers in Linguistics Series II, eds. T. Guy \& C. Harris, volume 6:27-56.

ElenbaAs, M. 2007. The Synchronic and Diachronic Syntax of the English Verb-Particle Combination. Nijmegen. Ph.D. dissertation.

EMONDS, J. 1972. Evidence that indirect object movement is a structure-preserving rule. Foundations of Language 8:546-561.

FARrell, P. 2005. English verb-preposition constructions: constituency and order. Language 81(1):96-137.

Fischer, O., Kemenade, A., van, Koopman, W. \& Wurff, W. van der. 2000. The Syntax of Early English. Cambridge: Cambridge University Press.

Foster, T. \& WURFF, W. VAN DER. 1997. From syntax to discourse: the function of the object-verb order in later Middle English. Studies in Middle English Linguistics, ed. J. Fisiak, 135-156. Berlin: Mouton de Gruyter.

FrASER, B. 1976. The verb-particle combination in English. New York/San Francisco/London: Academic Press.

Gries, S. 2000. Towards multifactorial analyses of syntactic variation: The case of particle placement. Hamburg. Ph.D. dissertation.

Haegeman, L. \& Guéron, J. 1999. English Grammar: A Generative Perspective. Oxford: Blackwell.

Haider, H. 2005. How to turn German into Icelandic - and derive the OV-VO contrasts. Journal of Comparative Germanic Linguistics 8:1-53.

HAIDER, H. 2007. Encounters of the third kind-On the hybrid headedness property of Old Germanic language. Paper presented at Information Structure and Word Order Variation in older Germanic, Humboldt University Berlin, 9-10 November 2007.

Hiltunen, R. 1983. The decline of the prefixes and the beginnings of the English phrasal verb: The evidence from some Old and Middle English texts. Turku: Turun Yliopisto.

Holmberg, A. 1986. Word order and syntactic features in the Scandinavian languages and English. Stockholm. Ph.D. dissertation.

Hoop, H. DE. 2003. Scrambling in Dutch: Optionality and Optimality. Word Order and Scrambling, ed. S. Karimi, 201-216. Oxford: Blackwell. 
Huddleston, R. \& Pullum, G. 2002. The Cambridge grammar of the English language. Cambridge: Cambridge University Press.

JACKendofF, R. 1973. The base rules for prepositional phrases. A Festschrift for Morris Halle, eds. S. R. Anderson \& P. Kiparsky, 345-356. New York: Holt, Rienhart and Winston.

JACKendoff, R. 1990. Semantic structures. Cambridge, MA: MIT Press.

KAYNE, R. 1994. The Antisymmetry of syntax. Cambridge, MA: MIT Press.

Kemenade, A. van. 2009. Discourse Relations and Word Order Change. Information structure and language change, eds. R. Hinterhölzl \& S. Petrova, 91-120. Berlin: Mouton de Gruyter.

Kemenade, A. van \& Los, B. 2003. Particles and prefixes in Dutch and English. Yearbook of Morphology 2003, eds. G. Booij \& J. van Marle, 79-117. Dordrecht: Kluwer.

Kemenade, A. van \& Los, B. 2006. Discourse adverbs and clausal syntax in Old and Middle English. The Handbook of the History of English, eds. A. van Kemenade \& B. Los, 224-248. Oxford: Blackwell.

Kemenade, A. van \& Milicev, T. 2011. Syntax and discourse in Old and Middle English word order, Grammatical Change. Origins, natures, outcomes, eds. D. Jonas, J. Whitman \& A. Garrett, 239-255. Oxford: Oxford University Press.

Kroch, A., Santorini, B. \& Delfs, L. 2004. Penn-Helsinki parsed corpus of Early Modern English. http://www.ling.upenn.edu/hist-corpora/PPCEMERELEASE- $1 /$.

Kroch, A. \& TAYlor, A. 2000a. Verb-complement order in Middle English. Diachronic Syntax: Models and Mechanisms, eds. S. Pintzuk, G. Tsoulas \& A. Warner, 132-163. Oxford: Oxford University Press.

Kroch, A. \& TAylor, A. 2000b. Penn-Helsinki parsed corpus of Middle English, 2nd ed. http://www.ling.upenn.edu/hist-corpora/PPCME2-RELEASE-2/.

LAmbrecht, K. 1994. Information Structure and Sentence Form: Topic, Focus, and the Mental Representations of Discourse Referents. Cambridge: Cambridge University Press.

Los, B., C. Blom, G. Booij, M. Elenbaas \& Kemenade, A. van. 2012. Morphosyntactic change: A comparative study of particles and prefixes. Cambridge: Cambridge University Press.

Neeleman, A. 1994. Complex Predicates. Utrecht. Ph.D. dissertation.

Neeleman, A. 2002. Particle placement. Verb-Particle Explorations, eds. N. Dehé, R. Jackendoff, A. McIntyre \& S. Urban, 141-164. Berlin: Mouton de Gruyter.

Neeleman, A. \& Koot, H. van De. 2008. Dutch scrambling and the nature of discourse templates. The Journal of Comparative Germanic Linguistics 11 (2):137-189.

PIntzuk, S. 1997. From OV to VO in the history of English. Ms. University of York.

PINTZUK, S. 2002. Verb-object order in Old English: variation as grammatical competition. Syntactic Effects of Morphological Change, ed. D. Lightfoot, 276299. Oxford: Oxford University Press.

Pintzuk, S. \& TAYlor, A. 2006. The loss of OV order in the history of English. The Handbook of the History of English, eds. A. vanKemenade \& B. Los, 249278. Oxford: Blackwell.

Pintzuk, S. \& TAYlor, A. 2008. The effect of information structure on object position in the history of English. Paper presented at ICEHL 15, University of Munich, 24-30 August 2009.

Randall, B. 2003. CorpusSearch 1.1. Philadelphia: University of Pennsylvania.

Spencer, A. \& Zaretskaya, M. 1998. Verb prefixation in Russian as lexical subordination. Linguistics 36:1-39. 
Svenonius, P. 1996. The optionality of particle shift. Working Papers in Scandinavian Syntax 57:47-75.

Svenonius, P. 2002. Verb-particles and separable prefixes. Handout I: Observable Syntax, 9th Central European Summer School in Generative Grammar, Novi Sad, 22 July - 2 August 2002.

Svenonius, P. 2003. Limits on $p$ : filling in holes vs. falling in holes. Nordlyd 31(2), 431-445.

Svenonius, P. 2007. Adpositions, particles and the arguments they introduce. Argument Structure, eds. E. Reuland, T. Bhattacharya \& G. Spathas, 63-103. Amsterdam: John Benjamins.

Talmy, L. 1978. Figure and ground in complex sentences. Universals of Human Language, Vol. 4, ed. J. Greenberg, 625-649. Stanford, CA: Stanford University Press.

Talmy, L. 2000. Toward a cognitive semantics, Vol. 1. Concept structuring systems. Cambridge, MA: MIT Press.

TAylor, A., Warner, A., Pintzuk, S. \& Beths, F. eds. 2003. The York-TorontoHelsinki parsed corpus of Old English prose. Oxford: Oxford Text Archive. http://www-users.york.ac.uk/ lang22/YcoeHome1.htm.

ToIvonen, I. 2002. Swedish particles and syntactic projection. Verb-Particle Explorations, eds. N. Dehé, R. Jackendoff, A. McIntyre \& S. Urban, 191-209. Berlin: Mouton de Gruyter.

Toivonen, I. 2003. Non-Projecting Words: A Case Study of Swedish Particles. Dordrecht: Kluwer.

WARNER, A. 1997. The structure of parametric change, and V-movement in the history of English. Parameters of Morphosyntactic Change, eds. A. van Kemenade \& N. Vincent, 380-393. Cambridge: Cambridge University Press.

Williams, E. 1981. On the notions 'lexically related' and 'head of a word'. Linguistic Inquiry 12:245-274.

Zeller, J. 2002. Particle verbs are heads and phrases. Verb-Particle Explorations, ed. N. Dehé, R. Jackendoff, A. McIntyre \& S. Urban, 233-267. Berlin: Mouton de Gruyter

Marion Elenbaas
LUCL/Department of English Language and Culture
University of Leiden
P.O. Box 9515
2300 RA, Leiden
The Netherlands
m.b.elenbaas@hum.leidenuniv.nl
Ans van Kemenade
CLS/Department of English
Radboud University Nijmegen
P.O. Box 9103
6500 HD, Nijmegen
The Netherlands
a.v.kemenade@let.ru.nl

